\title{
IMF concern for reputation and conditional lending failure: theory and empirics
}

\author{
Silvia Marchesi and Laura Sabani \\ University of Siena and University of Florence* \\ September 2004 \\ last revised April 2005
}

\begin{abstract}
One possible explanation for the unsatisfactory implementation of IMF conditionality has been attributed to the lack of credibility of the IMF threat of interrupting financial assistance in case of non compliance with the negotiated conditions. In this paper we suggest that such lack of credibility might be due to the dual role played by the IMF which acts at the same time as a creditor and a monitor of economic reforms. We show that the IMF incentive to hide its surveillance failures, in order to preserve its reputation of being a good monitor, may actually distort its lending decisions towards greater laxity (relative to social optimum) in punishing non-compliance with economic reforms. We have empirically tested such theoretical result by supposing that larger departures from efficiency of the IMF lending rule are associated with a longer relationship between a country and the IMF. The longer this relationship, the stronger the IMF reputation will be affected in case it ultimately decides to stop lending. Specifically, we have empirically investigated whether IMF disbursements are affected by the IMF own share of debt, which is taken as a proxy for the duration of the relationship between the Fund and a country. Our empirical results show that a higher IMF debt share does increase IMF disbursements.
\end{abstract}

Keywords: IMF programmes, conditionality, incomplete information, reputation, dynamic panel.

JEL Classification: C23, D82, F34, N2.

${ }^{*}$ We thank Axel Dreher, Beatriz Mariano, Marcus Miller and Alessandro Missale for helpful discussions, and seminar participants at the FMG/LSE Lunchtime Workshop and at the Warwick Development Workshop for comments. Marchesi gratefully acknowledges hospitality from the Financial Markets Group Research Centre (FMG). E-mail: marchesi@unisi.it; laura.sabani@unifi.it 


\section{Introduction}

On March 9th Argentina is supposed to make a scheduled repayment of money it owes to the International Monetary Fund.... If no payment is made, the IMF must set in train a process that would eventually declare Argentina in default, and that would be uncomfortable in the extreme for the IMF. The size-\$16 billion has been lent to Argentina-would be unprecedented, with consequences for the Fund's reputation and for the way it does business.... Certainly, the Fund has got into a position that its own experts would condemn if it were a commercial bank. Some 15\% of the Fund's total lending is to Argentina, a huge concentration. And with the $\$ 13.5$ billion, three-year facility agreed in September, the Fund is in effect continuing to lend large sums to what is in effect an insolvent debtor, on the understanding that it will use this to repay past loans.

Which is the victim? The Economist, Mar 4th 2004

In a nutshell, the Fund's current resources of $\$ 150$ billion seem like enough to cause moral-hazard problems (that is, to induce excessive borrowing) without being enough to deal with a really deep global financial crisis. The Fund is just too politicised to be a consistently effective lender of last resort, and if its financial structure is not changed, there are always going to be Argentinas. (If nothing else, there will always be Argentina.)

No, the right future for the Fund, as for the IBRD, is to phase itself out of the lending business. The Fund can still make itself very useful in co-ordinating the global financial system, in offering technical advice, and perhaps even in issuing debt ratings to countries that request it. If the global community can work its way towards an improved bankruptcy procedure for sovereign borrowers, this path will be far easier. I would recommend it regardless.

The sisters at 60 (Ken Rogoff). The Economist, July 22nd 2004

There exists a large body of evidence documenting an unsatisfactory record of IMF conditionality implementation by borrowing countries. ${ }^{1}$ Furthermore, the IMF has recently come under criticism for allowing some countries to establish long-term relationships, while, according to its original mandate, the Fund could only guarantee temporary assistance. Indeed, some countries have participated in a continuous series of Fund programmes over time and their duration has being increasing in recent decades (Joyce, 2004b). Moreover, a large proportion of IMF programmes are not successfully completed, with non-completion being not an indicator of graduation from the Fund but rather one of future referrals (on "recidivism" see Bird et al., 2004). ${ }^{2}$

What are the reasons adduced by the literature for conditional lending failure? They have generally been investigated looking at the characteristics of the borrowing

\footnotetext{
${ }^{1}$ For a review of this literature see Joyce (2004a).

${ }^{2}$ According to Mussa and Savastano (1999) only $47 \%$ of all IMF programmes have been successfully completed.
} 
countries, with more attention being recently devoted also to a country's political and institutional features. For example, Ivanova et al. (2003) conclude that programme implementation depends primarily on the domestic political economy of borrowing countries. More specifically, strong special interests, political instability, inefficient bureaucracies, lack of political cohesion and ethno-linguistic divisions are shown to weaken programme implementation. ${ }^{3}$

However, more recently, the possibility that the IMF specific interests may influence the adoption of an IMF programme (and in turn its implementation) has also been considered. For example, Barro and Lee (2003) find that IMF loans tend to be larger and more frequent when a country has a bigger quota and more professional staff at the IMF or when a country is more connected politically and economically to the United States and other major shareholders. In the case of low income countries (when IMF lending is highly concessional), Svensson (2000) argues that the welfare of the poors may enter the IMF utility function making not credible its threat of termination of financial assistance, when a country is not complying with conditionality.

Furthermore, according to the public choice approach to institutions (Vaubel, 1986, 1991), there would be a shift in responsibility from the executive directors to staff officials, who may decide to pursue the objectives of maximising their own budget and size without concern for the Fund mandate. Such a bureaucratic bias would lead the Fund to simply try to sign as many agreements as it can with the result that it may have little incentive to punish non compliance. Finally, Ramcharan (2003) presents an analytical model in which the IMF (as a creditor) could have little incentive to interrupt financial assistance to borrowing countries that did not manage to meet conditionality. When a country's debt becomes large enough to put its ability to repay at risk, for the IMF (as a creditor) may simply be optimal to keep on lending and rolling over the debt, until a debt restructuring mechanism (acting as a sort of bailout) becomes available. ${ }^{4}$ In turn, such a behaviour, if anticipated by a debtor country's government, would perversely affect its own willingness to reform. ${ }^{5}$

In this paper we join the view that the lack of credibility of the IMF threat of early terminating financial assistance can be responsible for conditionality failure. However,

\footnotetext{
${ }^{3}$ Since the success of a reform crucially depends on its successful implementation (which in turn reflects a country's political constraints) the IMF has been recently put much emphasis on a country's "ownership" of a programme (on this see, for example, Drazen, 2002).

${ }^{4}$ Marchesi and Missale (2004) have empirically confirmed that existing multilateral debt has a robust impact on multilateral new net loans to Heavily Indebted and Poor Countries (or HIPCs). In the case of Sub-Sahara countries, Birdsall et al. (2002) have found that donors, especially bilaterals, made greater transfers to countries with high multilateral debt, despite their bad policies.

${ }^{5}$ In the case of HIPCs, Easterly (2002) claims that multilateral creditors have worried so much about their liabilities not to pay enough attention to countries'ability to generate future income through economic growth. Moreover, this behaviour provided debtor countries with the incentives to avoid or postpone conditional reforms, since they anticipated that lenders would have given them loans anyway.
} 
we look at this problem from a different perspective, exploring the implications of the dual role of the IMF which simultaneously acts as a lender and as a monitor of economic reforms. In this context we take a political economy approach, where the IMF has its own objective function (which does not necessarily correspond to social optimum $)^{6}$ and we follow a stream of literature examining the policy implications of a self-interested bank regulator. ${ }^{7}$ Although this literature has been developed in a completely different framework, it actually offers useful insights for the issues tackled in this paper.

Bank regulators are supposed to monitor banks' risk taking in order to force compliance with regulation (on taxpayers' behalf). Furthermore, in case of financial distress, they should use the collected information to decide whether to support the bank (leave it in the market) or close it. Between global taxpayers and the IMF there exists a similar delegation problem: the IMF acts as a delegated monitor to assure country's compliance with the negotiated set of conditions. Besides, through the surveillance function, Fund officials collect private information that should be used to decide whether or not to continue financial assistance. It is this informative advantage which may allow a self-interested bank regulator/Fund to take actions that may sometimes contrast with the taxpayers'/global taxpayers' interest.

Building on Boot and Thakor (1993), we model the IMF self-interest by introducing uncertainty about its ability to monitor governments' implementation of conditionality. Global taxpayers, by observing a country's economic performance over time, can revise their beliefs about the IMF quality as a good monitor (it is assumed that the economic reforms imposed by conditionality improve expected output). This circumstance generates incentives for the IMF to take actions to protect its reputation as a good monitor and, in turn, this incentive can create significant departure from a socially optimal lending rule. The inefficiency stems from the fact that, due to its surveillance function, the IMF is always more informed than global taxpayers about the government real economic reform effort. This information advantage implies that the action of closing or continuing a programme not only provides global taxpayers with some information about a country's implementation of conditionality but also conveys information about the IMF quality as a monitor. We show that the desire to avoid a loss of reputation might lead the Fund to exhibit some laxity (relative to social optimum) in interrupting financial programmes when countries are not meeting conditionality. ${ }^{8}$ In turn, when the threat of stopping lending is not credible, borrowing countries' governments may not have the right incentives to fully comply with

\footnotetext{
${ }^{6}$ Self-interest in international financial institutions can take a variety of forms (see, for example, Allegret and Dulbecco, 2004).

${ }^{7}$ See Boot and Thakor (1993), Repullo (2000), Khan and Santos (2001).

${ }^{8}$ If the IMF supervisory information was observable, the circumstance that the Fund may be self-interested would not cause any problem since it could be forced to take the right actions by its constituency.
} 
conditionality. ${ }^{9}$

The length of the relationship between the IMF and the borrower country may exacerbate the departure from the socially optimal lending rule towards stronger laxity. In fact, when the Fund decides to interrupt a financial programme, after being involved with a country for many years, this circumstance could strongly signal that the Fund has not been able to monitor the implementation of reforms for a long time. In other words, the negative impact on IMF reputation of the decision to interrupt financial assistance should be an increasing function of the length of the relationship with the borrowing country.

We decided to empirically test the hypothesis that the longer the relationship between a country and the Fund the more willing to lend the IMF would be. More specifically, we empirically investigated whether a high debt and its composition by type of creditors played an important role in explaining the allocation of IMF disbursements, by taking the level of IMF outstanding debt as a proxy for the length of the relationship between the Fund and a country. ${ }^{10}$ According to our hypothesis, controlling for countries' characteristics and their economic performance, IMF disbursements should be correlated with the IMF own share of debt.

We estimated a dynamic panel of 53 middle-income countries (listed in Table 1) over the period 1982 to 2001, controlling for countries' characteristics and their economic performance and including both country-specific effects and time effects. We find that a higher level of IMF debt significantly increase IMF disbursements. Moreover, we find that larger loans went to countries in which commercial banks from industrial countries were highly exposed. ${ }^{11}$ Therefore, the empirical evidence looks consistent with the main prediction of the theory.

The paper is organized as follows. The model is developed in Section 2, the socially optimal closure rule and the government's first period choice of the level of reform are discussed in Section 3 and 4. Section 5 derives the reputational equilibrium. Section 6 develops the empirical framework and Section 7 presents the empirical results. Section 8 finally contains some policy implications and concludes the paper.

\footnotetext{
${ }^{9}$ We make the standard assumption that governments dislike the economic reforms imposed by conditionality either because they hinder the use of state apparatus to extract economic and political rents or to avoid a loss in their popularity. Among others see Svensson (2000) and Drazen (2002).

${ }^{10}$ The data actually show that the correlation between the two is very high (about 0.7 ).

${ }^{11}$ This is consistent with the evidence presented, among others, by Copelovitch (2004) who argues that IMF lending decisions are responsive to the interests of large industrial countries.
} 


\section{Theoretical model}

\subsection{Sequence of events}

In the model there are three agents: the IMF, the government of the country entering an IMF financial programme, and global taxpayers. All agents are risk neutral. Time extends over two periods.

At $\mathrm{t}=0$ the country has investments in place which pay-off at $\mathrm{t}=1$ a random amount: $\widetilde{y} \in[0, \bar{y}], F(),. f($.$) where F($.$) is a cumulative distribution function, f($. is the associated probability density function and $\bar{y}$ is a positive finite real valued scalar. Furthermore, at $t=0$, the country borrows $\$ 1$ from the IMF to finance a supplementary investment project whose expected payoff depends on the country's choice of a variable $R_{1}$. By $R_{1}$ we denote the degree of economic reform selected by the country's government in period 1 , with $R_{1} \in[0,1]$.

The supplementary investment payoff yields a random payoff $\widetilde{I}_{1}$ at the end of the first period. $\widetilde{I}_{1}$ may take the value of $I_{1}>1$, with probability $p_{1}\left(R_{1}\right) \in(0,1)$, and the value of 0 with the complementary probability. For simplicity we suppose that the IMF requires a risk-free interest rate that is assumed to be zero.

Assumption 1. We assume $p_{1}($.$) is a continuous twice differentiable concave func-$ tion of $R_{1}$. The function is strictly increasing within the range $R_{1} \in\left[0, R^{*}\right] .^{12}$

By undertaking economic reforms up to the level $R^{*}$ the government increases efficiency and thus enhances the expected payoff from the investment. However, since reforms eliminate economic and other distortions, they can also reduce the level of political and economic rents that can be extracted by the government for its private gain. Let $C_{1}\left(R_{1}\right)$ be the cost in terms of rents reduction associated to the economic reform level. We assume the following:

Assumption 2. $C_{1}($.$) is a continuous twice differentiable increasing convex function$ of the economic reform level, where $C_{1}(0)=0^{13}$

At $\mathrm{t}=1$ the country realises $\widetilde{y}+\widetilde{I}_{1}$ and first period debt is paid off. It now needs a second loan to finance another investment project. The new investment also requires $\$ 1$ to be financed. We suppose that, whatever the realized payoff at $t=1$ is, the country always needs IMF financial assistance, that is $\bar{y}+I_{1}<2$. If $\widetilde{y}+\widetilde{I}_{1}$ is less than 1 , the government can not repay first period debt. In this case, if financial assistance is continued, first period debt is postponed to the end of the second period, while, if

\footnotetext{
${ }^{12} \mathrm{~A}$ degree of economic reforms exceeding $R^{*}$ has negative effects. This could be explained by referring to output losses due to social conflicts generated by reforms. For example, if the labour force feels that an IMF adjustment program is imposing an unnecessary hardship, the government may lack the societal support to continue the adjustment program and efficiency may suffer. In general it is realistic to consider the economic reform process as a sequential process in which time is essential to allow the economy to adapt to the new environment.

${ }^{13}$ We also assume that $\frac{\partial p_{1}(0)}{\partial R_{1}}>\frac{\partial C_{1}(0)}{\partial R_{1}}$ to avoid corner solutions in the maximisation problem.
} 
it is interrupted, the IMF loses $\widetilde{y}+\widetilde{I}_{1}-1$. The assets in place at $\mathrm{t}=0$ expire at $\mathrm{t}=1$ and so there is no payoff from those assets at $t=2$.

If the country is allowed to continue, we assume that the new investment has a random payoff $\widetilde{I}_{2}$ which takes the value of $I_{2}>2^{14}$ with probability $p_{2}\left(R_{2}\right)$ and the value of 0 with the complementary probability. By $R_{2}$ we denote the degree of economic reform selected by the government in period 2 , with $R_{2} \in[0,1]$.

Assumption 3. If $R_{1} \neq R^{*}, p_{2}()=.p_{1}($.$) ; if R_{1}=R^{*}, p_{2}()=.p_{1}()+.\alpha$, where $\alpha$ is a positive finite real valued scalar such that $p_{1}\left(R^{*}\right)+\alpha<1$.

From assumptions 1 and 3 it follows that $p_{2}($.$) is strictly increasing within the$ range $R_{2} \in\left[0, R^{*}\right]$. Furthermore we assume that the probability of success of the second period project has a "jump" when the social optimal level of economic reforms $R^{*}$ is attained in the first period. The rationale behind this hypothesis rests on the fact that financial assistance is more productive in a good policy environment. Moreover, in period 2, economic and political rents are a decreasing function of the second period reform effort. For simplicity we impose the following:

$$
\text { Assumption 4. } C_{2}(.)=C_{1}(.)
$$

\subsection{Role of IMF}

The IMF is entrusted with two tasks:

1) The IMF identifies and suggests the level of economic reforms $R^{*}$ which maximizes the first period country output and monitors the government's reform effort. Due to its quality as a good monitor, the IMF has the possibility to discover departures from the optimal reform level $R^{*}$ early enough to "enforce" the corrections needed to reach it by the end of the first period. This power comes from the threat of immediately interrupting the programme and soon recovering the initial loan by seizing the assets in place and getting back the fraction of the loan not yet been spent. Facing this threat, due to the impossibility of completing the investment project, the government will be forced to choose the optimal reform level $R^{*} \cdot{ }^{15}$ If the IMF does not detect such departures early enough, the reform level achieved by the end of the first period will be the one which is privately preferred by the government.

2) The second task consists in the decision to refinance the country at $t=1$. At the end of the first period, the IMF is able to observe the actual level of reforms and it has to decide whether or not to continue lending. In the second period, for simplicity we exclude the possibility of monitoring. Moreover, since the economy terminates at the end of it, at this point, the IMF is not able any more to influence the choice

\footnotetext{
${ }^{14}$ This restriction guarantees that the government strictly prefers to be allowed to finance the second period project at $t=1$, even when the total first period payoff is very low.

${ }^{15}$ In our model, the interim period is meant to capture the traditional structure of an IMF loan, which is divided into tranches and where the access to successive tranches is guaranteed by the implementation of conditionality.
} 
of reform effort by the threat of lending termination. Thus, the IMF is not able to control the second period economic reform level.

Assumption 5. The IMF can be of two types: a good monitor or a bad monitor. If it is a good monitor it will manage to enforce $R^{*}$ at the end of the first period with probability $\rho_{g}$, if it is a bad monitor the probability would be $\rho_{b}$, with $\rho_{g}>\rho_{b}$.

At $\mathrm{t}=0$, the IMF type is unknown to everybody but global taxpayers and the country's government have got a prior belief $\gamma \in(0,1)$ that it is a good monitor ${ }^{16}$. At $\mathrm{t}=1$ the IMF observes the choice of $R_{1}$ and $\widetilde{y}+\widetilde{I}_{1}$. Global taxpayers, at this stage, do not observe anything apart from the IMF decision to refinance or not refinance the country. At $\mathrm{t}=2$, global taxpayers observe the realisation of the first period output $\widetilde{y}+\widetilde{I}_{1}$. The sequence of events is described in Figure 1 .

The IMF maximizes a weighted sum of two arguments. The first is a "private" gain deriving from its reputation as a good monitor, the second is the social surplus arising from second period investment:

$$
\operatorname{Max} \lambda_{1}\left\{\gamma_{1}+\delta \gamma_{2}\right\}+\lambda_{2}\left\{p_{2}\left(R_{2}\right) I_{2}-1\right\}
$$

where $\lambda_{1}, \delta, \lambda_{2}$ are positive finite real valued scalars and $\gamma_{1}, \gamma_{2}$ are global taxpayers posterior beliefs about the IMF type at the end of the first and the second period, respectively. ${ }^{17}$ If $\lambda_{1}=0$, the IMF would be totally "selfless", while if $\lambda_{2}=0$, the IMF would be completely "selfish".

At $\mathrm{t}=0$, the government chooses $R_{1}$ to maximize the expected profits over the two periods. The "continuation probability" is computed on the basis of the IMF conjectured lending policy, to be defined below. At $\mathrm{t}=1$, if financial assistance is continued, the government chooses $R_{2}$ to maximize the second period expected profits.

\section{Socially optimal lending rule}

Whatever the realization of the first period investment and the payoff from assets in place at $\mathrm{t}=1$ are, it will be socially optimal to continue lending if:

$$
p_{2}\left(R_{2}\right) I_{2} \geq 1
$$

Thus, the socially optimal lending rule would dictate to stop lending whenever the second period reform level chosen by the government is such that the project's NPV is negative.

\footnotetext{
${ }^{16}$ For example, the existence of uncertainty over the IMF monitoring ability could be explained by the uncertainty over the ability of the executive directors to monitor the activity of staff officials.

${ }^{17}$ We do not include an IMF budget constraint since the Fund can activate supplementary borrowing arrangements (through $\mathrm{GAB}$ and $\mathrm{NAB}$ ) if it believes that its resources might fall short of members' needs. In turn, such IMF ability depends on its reputation where reputation building is indeed an argument of the Fund objective function.
} 
By assumption 3, the socially optimal choice for $R_{2}$ is:

$$
R^{*}=\operatorname{argmax} p_{2}\left(R_{2}\right)
$$

To better define the socially optimal lending rule, we have to solve for the actual second period reform level that a government, with own capital equal to $\widetilde{y}+\widetilde{I}_{1}-1=\widetilde{k}$, would choose. The government solves the following optimization problem:

$$
\underset{R_{2}}{\operatorname{Max}} l\left(R_{2}\right)=p_{2}\left(R_{2}\right)\left(I_{2}-(1-\widetilde{k})\right)-\widetilde{k}-C_{2}\left(R_{2}\right)
$$

where first period reform level is given.

Solving (4) we find that the unique maximizer of (4) $\widehat{R}_{2}$ is implicitly given by:

$$
\frac{\frac{\partial C_{2}\left(\widehat{R}_{2}\right)}{\partial R_{2}}}{\frac{\partial p_{2}\left(\widehat{R}_{2}\right)}{\partial R_{2}}}=I_{2}+\widetilde{k}-1
$$

Proposition 1 (i) $\widehat{R}_{2}<R^{*}$ unless $\frac{\partial C_{2}\left(R_{2}\right)}{\partial R_{2}}=0$. (ii) $\frac{\partial \widehat{R}_{2}(\widetilde{k})}{\partial \widehat{k}}>0$

Proof. (i) It is immediate from equation (5) (ii) It derives from equation (5) and the implicit function theorem.

Proposition 1 implies that the lower the country's second period own capital (i.e. the higher the IMF financial assistance), the lower the reform effort chosen by the government in the second period. This result is quite intuitive since the debt overhang reduces the ownership on the project's output, whereas the cost of reforms in terms of rents reduction are always entirely borne by the government.

Assumption 6. If $R_{1}=R^{*}$, it is socially optimal to continue lending, that is:

$$
\left(p_{1}\left(\widehat{R}_{2}(\widetilde{k})\right)+\alpha\right) I_{2}>1 \quad \forall \widetilde{k}
$$

Assumption 6 implies that, if in the first period the IMF manages to enforce the socially optimal level of reforms, the net present value of the second period project will be positive, independently of the second period choice of reform effort. ${ }^{18}$ Thus, accomplishment of conditionality in the first period is a sufficient condition for having access to a financial programme at $t=1$, under a socially optimal lending rule. We can now state the following proposition:

Proposition 2 If $R_{1} \neq R^{*}$ there exists a threshold level for $\widetilde{k}$ such that if $\widetilde{k}<\bar{k}$ it is economically rational for the IMF to stop lending. If $\widetilde{k} \geqslant \bar{k}$, it is socially optimal to continue, where $\bar{k}$ is found solving $p_{2}\left(\widehat{R}_{2}(\bar{k})\right) I_{2}=1$.

\footnotetext{
${ }^{18}$ This assumption helps simplifying the analysis. However, our results would be substantially unaffected by the alternative assumption that for low level of capital the project's NPV is negative.
} 
When the IMF follows a socially optimal lending rule, choosing a high level of reforms in the first period, provides insurance against early termination of the programme (due to adverse shocks) because by increasing the first period reform effort the probability of low realizations of $\widetilde{k}$ is reduced. At the limit, i.e. when $R_{1}=R^{*}$, the probability of continuing with the programme is one.

\section{The equilibrium level of first period economic reforms}

In this section we want to derive the government's privately optimal level of first period reforms. We start by assuming that the government's privately optimal level of first period reforms is always less than $R^{*} \cdot{ }^{19}$ First of all we analyse the case in which the IMF will never stop lending, while we will analyse below the case in which the IMF will follow the socially optimal lending rule. Let $\widehat{R}_{1}^{L}$ represent the government's privately optimal first period reform under the assumption that the IMF is always willing to lend. Let's now define the expected profits to the government for acceding to the second loan as follows:

$$
\begin{aligned}
L\left(R_{1}\right)= & p_{1}\left(R_{1}\right) \int_{0}^{\bar{y}} p_{2}\left(\widehat{R}_{2}\left(\widetilde{k}^{s}\right)\right)\left(I_{2}-\left(1-\widetilde{k}^{s}\right)\right)-\widetilde{k}^{s}-C_{2}\left(\widehat{R}_{2}\left(\widetilde{k}^{s}\right)\right) f(y) d y+ \\
& \left(1-p_{1}\left(R_{1}\right)\right) \int_{0}^{\bar{y}} p_{2}\left(\widehat{R}_{2}\left(\widetilde{k}^{f}\right)\right)\left(I_{2}-\left(1-\widetilde{k}^{f}\right)\right)-\widetilde{k}^{f}-C_{2}\left(\widehat{R}_{2}\left(\widetilde{k}^{f}\right)\right) f(y) d y
\end{aligned}
$$

where $\widetilde{k}^{s}$ is the country's own capital in case of success of the first period investment while $\widetilde{k}^{f}$ is the level of capital in case of failure.

Let $\rho=\gamma \rho_{g}+(1-\gamma) \rho_{b}$ be the prior belief-weighted probability that the IMF will be able to enforce the choice of $R^{*}$ in the first period and let $\phi\left(R_{1}\right)=p_{1}\left(R_{1}\right)\left(I_{1}-1\right)-$ $C_{1}\left(R_{1}\right)$ denote the government's expected profits from the first period investment project. We can now write the country's government problem, at $\mathrm{t}=0$, as that of choosing $R_{1}$ to maximize the following:

$$
X\left(R_{1}\right)=(1-\rho)\left(\phi\left(R_{1}\right)+L\left(R_{1}\right)\right)+\rho\left(\phi\left(R^{*}\right)+L\left(R^{*}\right)\right)
$$

$\widehat{R}_{1}^{L}$ satisfies the following:

$$
\frac{\partial X\left(\widehat{R}_{1}^{L}\right)}{\partial R_{1}}=(1-\rho)\left(\frac{\partial \phi\left(\widehat{R}_{1}^{L}\right)}{\partial R_{1}}+\frac{\partial L\left(\widehat{R}_{1}^{L}\right)}{\partial R_{1}}\right)=0 .
$$

\footnotetext{
${ }^{19}$ This assumption is needed in order to exclude that the increase in the second period probability of success $(\alpha)$, due to the choice of $R^{*}$, would be sufficient to induce the government to choose the social optimum level of effort. However, the case in which the IMF and the recipient government had the same objectives would not be very interesting per sé.
} 
We want now to examine the relationship between $\widetilde{k}$ and the second period profits. From equation (4) we obtain:

$$
l\left(\widehat{R}_{2}(\widetilde{k})\right)=p_{2}\left(\widehat{R}_{2}(\widetilde{k})\right)\left(I_{2}-(1-\widetilde{k})\right)-\widetilde{k}-C_{2}\left(\widehat{R}_{2}(\widetilde{k})\right)
$$

where $\widehat{R}_{2}(\widetilde{k})$ is given by (5) and (9) represents, for each value of $\widetilde{k}$, the maximum value of the second period expected profits of the government, conditional on being allowed to continue.

Proposition 3 At the beginning of the second period for a given choice of the first period reform, the government is better off with a lower capital, conditional on being allowed to continue.

Proof. Using the envelope theorem, it is easy to show that:

$$
\frac{\partial l\left(\widehat{R}_{2}(\widetilde{k})\right)}{\partial \widetilde{k}}=p_{2}\left(\widehat{R}_{2}\right)-1<0 .
$$

Proposition 3 tells us that the government has an interest in undertaking actions in the first period that result in a lower expected capital in the second period, conditional on being allowed to continue. Therefore, given the positive relationship between $R_{1}$ and the expected value of $\widetilde{k}\left(\frac{\partial E_{0}\left(\widetilde{k} \mid R_{1}\right)}{\partial R_{1}}>0\right)$, the government's incentive to implement economic reforms would be perversely affected. More specifically:

Proposition 4 Conditional on being allowed to finance the second period project, the government has an incentive to choose a lower level of reforms $R_{1}$ than it would choose in a single-period setting .

Proof. It is obvious by observing that $\frac{\partial L\left(R_{1}\right)}{\partial R_{1}}<0 \forall R_{1}$. Thus, when $R_{1}=\widehat{R}_{1}^{L}$, by equation (8), $\frac{\partial \phi\left(R_{1}\right)}{\partial R_{1}}>0$.

Suppose now that the IMF will refuse to concede a new loan whenever $\widetilde{k}<\bar{k}$ and let's assume that $\widetilde{k}^{s}>\bar{k}$, for each realisation of $\widetilde{y}$. On the contrary, when $\widetilde{k}=\widetilde{k}^{f}$, let $y_{c}=\bar{k}+1$ be the minimum realisation of $\widetilde{y}$ which allows the government to obtain the second loan in case of failure of the first period project. Let's now define $M\left(R_{1}, y_{c}\right)$ as the second period expected profits, conditional on the socially optimal lending rule:

$$
\begin{aligned}
M\left(R_{1}, y_{c}\right)= & p_{1}\left(R_{1}\right) \int_{0}^{\bar{y}} p_{2}\left(\widehat{R}_{2}\left(\widetilde{k}^{s}\right)\right)\left(I_{2}-\left(1-\widetilde{k}^{s}\right)\right)-\widetilde{k}^{s}-C_{2}\left(\widehat{R}_{2}\left(\widetilde{k}^{s}\right)\right) f(y) d y+(10) \\
& \left(1-p_{1}\left(R_{1}\right)\right) \int_{y_{c}}^{\bar{y}} p_{2}\left(\widehat{R}_{2}\left(\widetilde{k}^{f}\right)\right)\left(I_{2}-\left(1-\widetilde{k}^{f}\right)\right)-\widetilde{k}^{f}-C_{2}\left(\widehat{R}_{2}\left(\widetilde{k}^{f}\right)\right) f(y) d y
\end{aligned}
$$


It is immediate to verify that:

$M\left(R_{1}, y_{c}\right)=L\left(R_{1}\right)-\left(1-p_{1}\left(R_{1}\right)\right) \int_{0}^{y_{c}} p_{2}\left(\widehat{R}_{2}\left(\widetilde{k}^{f}\right)\right)\left(I_{2}-\left(1-\widetilde{k}^{f}\right)\right)-\widetilde{k}^{f}-C_{2}\left(\widehat{R}_{2}\left(\widetilde{k}^{f}\right)\right) f(y) d y$

Thus, the government problem, at $\mathrm{t}=0$, now becomes that of choosing $R_{1}$ to maximize the following:

$$
X\left(R_{1}, y_{c}\right)=(1-\rho)\left(\phi\left(R_{1}\right)+M\left(R_{1}, y_{c}\right)\right)+\rho\left(\phi\left(R^{*}\right)+L\left(R^{*}\right)\right)
$$

Let now $\widehat{R}_{1}^{S O}$ be the level of first period reform which maximises (12).

Proposition 5 If the IMF will refuse credit continuation whenever $\widetilde{y}<y_{c}$ the desire to preserve second period profits will induce the government to choose a higher reform level in the first period, that is $\widehat{R}_{1}^{S O}>\widehat{R}_{1}^{L}$

Proof. To prove the result it is sufficient to show that:

$$
\left.\frac{\partial X\left(R_{1}, y_{c}\right)}{\partial R_{1}}\right|_{R_{1}=\widehat{R}_{1}^{L}}>0
$$

From equation (8) noting that:

$$
\frac{\partial \phi\left(R_{1}\right)}{\partial R_{1}}+\left.\frac{\partial L\left(R_{1}\right)}{\partial R_{1}}\right|_{R_{1}=\widehat{R}_{1}^{L}}=0
$$

we have:

$$
\begin{aligned}
& \left.\frac{\partial X\left(R_{1}, y_{c}\right)}{\partial R_{1}}\right|_{R_{1}=\widehat{R}_{1}^{L}}= \\
& -(1-\rho)\left(\frac{\partial\left(1-p\left(R_{1}\right)\right)}{\partial R_{1}}\right) \int_{0}^{y_{c}} p_{2}\left(\widehat{R}_{2}\left(\widetilde{k}^{f}\right)\right)\left(I_{2}-\left(1-\widetilde{k}^{f}\right)\right)-\widetilde{k}^{f}-C_{2}\left(\widehat{R}_{2}\left(\widetilde{k}^{f}\right)\right) f(y) d y
\end{aligned}
$$

where the right hand side is surely positive.

\section{Lending policy in a reputational equilibrium}

In this section we want to examine whether the socially optimal lending policy is sustainable in equilibrium. We start by assuming that the market (both global taxpayers and the country's government) believe that the IMF will stop lending whenever $\widetilde{k}<\bar{k}$ and we will show that this belief is unsustainable in equilibrium. The first thing to show is that it is always true that: $\gamma_{1}(N L)<\gamma_{1}(L)$, where NL stands for Not Lending and L for Lending. 
If global taxpayers observe $\mathrm{L}$ this can be the consequence of two events: either $R_{1}=R^{*}$, or $R_{1}=\widehat{R}_{1}^{S O}$ and $\widetilde{k}>\bar{k}$. Applying Bayes' rule we have

$$
\gamma_{1}(L)=\operatorname{prob}(g \mid L)=\frac{\gamma \operatorname{prob}(L \mid g)}{\gamma \operatorname{prob}(L \mid g)+(1-\gamma) \operatorname{prob}(L \mid b)}
$$

where:

$$
\operatorname{prob}(L \mid g)=\rho_{g}+\left(1-\rho_{g}\right) \int_{\bar{k}}^{I+\bar{y}-1} h\left(\widetilde{k} \mid R_{1}=\widehat{R}_{1}^{S O}\right) d \widetilde{k}
$$

and

$$
\operatorname{prob}(L \mid b)=\rho_{b}+\left(1-\rho_{b}\right) \int_{\bar{k}}^{I+\bar{y}-1} h\left(\widetilde{k} \mid R_{1}=\widehat{R}_{1}^{S O}\right) d \widetilde{k}
$$

by which it is easy to show that $\gamma_{1}(L)>\gamma$, noting that (14) is greater than (15). ${ }^{20}$ Alternatively, if global taxpayers observe $N L$, this event signals that the joint event $R_{1}<R^{*}$ and $\widetilde{k}<\bar{k}$ has realized. The interruption of the lending programme provides global taxpayers with the information that the IMF has not been able to monitor and finally enforce the optimal level of reforms. Since this is more likely for a bad monitor than for a good monitor, applying Bayes' rule, we have:

$$
\gamma_{1}(N L)=\operatorname{prob}(g \mid N L)=\frac{\gamma \operatorname{prob}(N L \mid g)}{\gamma \operatorname{prob}(N L \mid g)+(1-\gamma) \operatorname{prob}(N L \mid b)}
$$

where

$$
\operatorname{prob}(N L \mid g)=1-\rho_{g}
$$

and

$$
\operatorname{prob}(N L \mid b)=1-\rho_{b}
$$

by which it is easy to show that $\gamma_{1}(N L)<\gamma$. Therefore $\gamma_{1}(N L)<\gamma<\gamma_{l}(L)$.

If the IMF was completely selfish its objective function would be the first argument of (1). If the financial assistance programme was stopped at the end of the first period the IMF would end up with:

$$
\gamma_{1}(N L)+\delta \gamma_{1}(N L)
$$

since $\gamma_{1}=\gamma_{2}$. While, if the IMF did not stop lending, it would obtain:

$$
\gamma_{1}(L)+\delta \gamma_{2}(L, \widetilde{k})
$$

Proposition $6 \quad \gamma_{2}(L, \widetilde{k})>\gamma_{1}(N L) \quad \forall \widetilde{k}$

\footnotetext{
${ }^{20} h$ is the probability density function of the sum of the two stochastic variables $\widetilde{I}_{1}$ and $\widetilde{y}$.
} 
Proof. (i) If $\widetilde{k}>\bar{k}$, global taxpayers, applying Bayes' rule, would obtain:

$$
\begin{aligned}
& \operatorname{prob}(L, \widetilde{k}>\bar{k} \mid g)=\rho_{g} \operatorname{prob}\left(\widetilde{k}>\bar{k} \mid R_{1}=R^{*}\right)+\left(1-\rho_{g}\right) \operatorname{prob}\left(\widetilde{k}>\bar{k} \mid R_{1}=\widehat{R}_{1}^{S O}\right) \\
& \operatorname{prob}(L, \widetilde{k}>\bar{k} \mid b)=\rho_{b} \operatorname{prob}\left(\widetilde{k}>\bar{k} \mid R_{1}=R^{*}\right)+\left(1-\rho_{b}\right) \operatorname{prob}\left(\widetilde{k}>\bar{k} \mid R_{1}=\widehat{R}_{1}^{S O}\right)
\end{aligned}
$$

Since $\frac{\partial E_{0}\left(\widetilde{k} \mid R_{1}\right)}{\partial R_{1}}>0$, we observe that

$$
\frac{\operatorname{prob}(L, \widetilde{k}>\bar{k} \mid b)}{\operatorname{prob}(L, \widetilde{k}>\bar{k} \mid g)}<\frac{1-\rho_{b}}{1-\rho_{g}}
$$

by which it is easy to show the result.

(ii) $\widetilde{k}<\bar{k}$, given the conjectured equilibrium strategies, this observation would be consistent only with the choice of $R_{1}=R^{*}$, then:

$$
\frac{\operatorname{prob}(L, \widetilde{k}<\bar{k} \mid b)}{\operatorname{prob}(L, \widetilde{k}<\bar{k} \mid g)}=\frac{\rho_{b}}{\rho_{g}}<\frac{1-\rho_{b}}{1-\rho_{g}}
$$

and the result is straightforward.

Therefore, it follows that, for each level of $\widetilde{k}$ observed by global taxpayers at the end of the second period, it would never be rational for the "completely selfish" IMF to interrupt the financial assistance programme. Thus, when the IMF is totally selfish, the socially optimal lending rule cannot be sustainable in equilibrium. ${ }^{21}$ Alternatively, when the IMF objective function is a mix of the two arguments (reputation and second period project's NPV), the IMF will weight the reputation loss deriving from the decision of stopping the programme against the welfare loss deriving from the decision to finance a negative NPV project. In this case, the following Proposition describes the IMF optimal strategies, given the global taxpayers equilibrium beliefs.

Proposition 7 The following strategies and beliefs constitute a Bayesian subgame perfect equilibrium.

IMF equilibrium strategies (reputational lending rule).

When $R_{1}=R^{*}$, the IMF will continue lending whatever the level of capital is. When $R_{1} \neq R^{*}$, the IMF will stop lending if $\widetilde{k} \leq \overleftarrow{k}$, while it will continue lending if $\widetilde{k} \geqslant \vec{k}$. For intermediate $\widetilde{k}$, i.e. $\overleftarrow{k}<\widetilde{k}<\vec{k}$, the IMF will continue lending with probability $\theta(\widetilde{k})$, where $\frac{\partial \theta(\widetilde{k})}{\partial \widetilde{k}}>0$ and $\theta(\vec{k})=1$ and $\theta(\overleftarrow{k})=0$

Global taxpayers equilibrium beliefs.

First stage.

If global taxpayers observe L, they would know that this can be due to two events: either $R_{1}=R^{*}$ or, with probability $\theta(\widetilde{k}), R_{1} \neq R^{*}$ and $\widetilde{k}>\overleftarrow{k}$, and they would

\footnotetext{
${ }^{21}$ When the IMF is completely selfless (i.e. it is just a social surplus maximizer) it will always apply the socially optimal lending rule and so this will be the only possible equilibrium.
} 
update their beliefs accordingly, using Bayes' rule. Alternatively, if they observe NL, they would know with certainty that $R_{1} \neq R^{*}$ and they would update their beliefs accordingly using Bayes' rule.

Second stage.

(i) L has been observed at $t=1$. If global taxpayers observe $\widetilde{k} \leq \overleftarrow{k}$ they would know with certainty that $R_{1}=R^{*}$ and they would update their beliefs accordingly, using Bayes' rule. If global taxpayers observe $\widetilde{k}>\overleftarrow{k}$ they would know that this can be due because of two events: either $R_{1}=R^{*}$ or, with probability $\theta(\widetilde{k}), R_{1} \neq R^{*}$ and $\widetilde{k}>\overleftarrow{k}$, and they would update their beliefs accordingly using Bayes' rule.

(ii) $N L$ has been observed at $t=1$. Since the information set remains the same over the two periods: $\gamma_{1}=\gamma_{2}$.

Proof. See the Appendix

Proposition 7 implies that in equilibrium the IMF will stop lending less often than it would be recommended by a socially optimal lending rule. Figure 2 represents the welfare loss and the private gain in reputation of the IMF as a function of the level of capital $\widetilde{k}$. Three relevant cases are represented, according to the value of $\widetilde{k}$. If $-1 \leq \widetilde{k} \leq \overleftarrow{k}$, since the welfare loss associated to the choice of lending is greater than the private gain in reputation, the IMF will not have any incentive to deviate from the equilibrium strategy not lending (NL). Alternatively, if $\vec{k} \leq \widetilde{k} \leq \bar{k}$, the private gain in reputation associated to lending (L) is greater than the welfare loss (when $R_{1} \neq R^{*}$ ), and so the Fund will lend with probability one. Finally, if $\overleftarrow{k} \leq \widetilde{k} \leq \vec{k}$, for the equilibrium strategies to be consistent with the equilibrium beliefs, the probability of lending $(\theta(\widetilde{k}))$ should be such that the private gain in reputation from choosing lending is exactly offset by the welfare loss (when $R_{1} \neq R^{*}$ ), namely the IMF should be indifferent between L and NL.

Proposition 8 Given the IMF reputational lending rule, $\widehat{R}_{1}^{R}$ is the value of $R_{1}$ which maximises the government's expected profits over the two periods. We have that $\widehat{R}_{1}^{R}<$ $\widehat{R}_{1}^{S O}$.

Proof. Since in equilibrium the IMF will stop lending less often than it would be recommended by a socially optimal lending rule, this result is proved by applying Proposition 5

Lemma 9 The reform level chosen by the government in the first period is a decreasing function of the weight that the IMF attaches to the pursuit of its reputation as a good monitor.

Proof. This result easily follows noting that:

$$
\frac{\partial \overleftarrow{k}}{\partial \lambda_{1}}<0
$$


that is, the greater the weight that the IMF attaches to its reputation gain, the lower the threshold level of capital that would prevent the country from obtaining a second loan. Therefore, the departure from the socially optimal lending rule increases with $\lambda_{1}$.

The threat of future termination of an IMF programme is meant to be the main factor which may contrast the government's adverse incentives towards reforming. However, we have shown that if the IMF cares about its reputation as a good monitor, the existence of uncertainty about its ability to enforce conditionality can distort its lending policy towards a too lax behaviour. This in turn implies a departure from the socially optimal level of reform in the first period of the programme. Moreover, the more lax the lending policy, the higher the probability of financing a negative NPV project in the second period, since the level of second period reform is an increasing function of a country's capital.

\section{Empirical model}

The main result of the theoretical model implies that the desire to avoid a loss of reputation might lead the IMF to exhibit some laxity (relative to social optimum) in interrupting financial programmes. Furthermore, the longer the IMF has been involved with a country's reforms, the more its reputation as a good monitor could be damaged if it decides to stop lending. Thus, taking the IMF share of debt as a proxy for the length of the relationship between the Fund and a country, in this section we empirically test the hypothesis that the longer this relationship the more willing to lend the IMF would be. More specifically, we expect to find a positive correlation between IMF disbursements and the lagged value of the IMF own debt share.

We will examine the behaviour of IMF disbursements for the period 1982- 2001. The reason we focus on this period is that the debt crisis of the early 1980s arguably marked a shift in regime. Data on loans are from Global Development Finance (GDF) and World Development Indicator (WDI) statistics of the World Bank. We confine our attention to long-term loans (except in the IMF case where there is no such distinction), since the GDF database does not provide any information on the type of creditor in the case of short-term loans. However, Figure 3 shows that short-term loans have been a small share of total loans for the period under investigation and thus long-term loans are fairly representative of the aggregate.

We estimate a dynamic panel of 53 middle-income countries, over the years 19822001, including both country-specific and time effects. Data availability has also limited the sample group to 53 middle-income countries, instead of the original 93 countries. We have chosen a dynamic specification, i.e. we included a lag of the dependent variable among the regressors, to account for the short run dynamics of 
IMF disbursements. The dynamic specification allows for a correct estimation of the effect of high levels of debt by controlling for the autocorrelation of IMF disbursements. Moreover, we included lagged values of most of the regressors to control for endogeneity.

The estimated equations for net loans and grants are as follows:

$$
D_{i, t}=b_{0}+b_{1} D_{i, t-1}+b_{2} D_{i, t-1}^{j}+b_{3} B_{i, t-1}^{j}+b_{4} Z_{i, t-1}+b_{5} C_{i}+b_{6} T_{t}+b_{7} H_{i} B_{i, t-1}^{j}
$$

where $D_{i, t}$ denotes IMF disbursements (relative to GDP) to country $i$ and $D_{i, t-1}^{j}$ denotes long-term disbursements (relative to GDP) to country $i$ from creditor $j$ (i.e. bilateral, multilateral and private creditors, as distinguished between commercial banks loans and bonds). To examine the relation between IMF disbursements and a country's degree of indebtedness, we consider the stock of debt owed to the IMF and the stock of long-term debt (relative to GDP) owed to bilateral, multilateral and private creditors (distinguished between commercial banks and private bondholders) and enter the five types of debt separately. That is, $B_{i, t-1}^{j}$ is the vector of the stocks of debt held by different creditors. $^{22}$

To control for countries characteristics, we include the set of variables $Z_{i, t-1}$ as explanatory variables. They have been chosen among those suggested by the literature on IMF loans determinants, which, however, does not specifically distinguish between the determinants of the loan amount and the determinants of the arrangements themselves. As Knight and Santaella (1997) point out, the regressions can be interpreted as a reduced form derived from both the "demand" for an IMF programme by a recipient country and the IMF "supply". In the "demand side," their estimates suggest that lower level of international reserves, per capita GDP, domestic investment and higher values of the external debt service, movements in the real exchange rate, a dummy indicating previous Fund arrangements are significant determinants of a country's interest in a Fund arrangement. Among the supply factors, they find that policy measures to increase fiscal revenue, to reduce government expenditure, to tighten domestic credit and to adjust the exchange rate, positively affect the Fund approval of an arrangement. More recently, following the increasing interest on the impact of political and institutional factors on economic performance, ${ }^{23}$ political, institutional and social type of variables have also been considered. According to Sturm et al. (2004), however, while mostly economic variables are robustly related to IMF lending activity, most political variables are non-significant. ${ }^{24}$

Therefore, the set $Z_{t-1}$ include (previous year) economic performance as measured with the per capita income, the rate of inflation, GDP growth, the amount of international reserves (to imports), the current account balance (to GDP), the domestic

\footnotetext{
${ }^{22}$ Figure 4 actually presents the pattern of these debt shares in the period 1981-'01.

${ }^{23}$ Among others, see Acemoglu et al. (2001) and Knack and Keefer (1995).

${ }^{24}$ To the extent that political factors matter, they seem more closely related to the conclusion of an agreement with the IMF than to the disbursement of an IMF loan.
} 
(fixed) investments (to GDP), the growth of government consumption (to GDP), total debt service (to exports). These variables should control for the demand side of IMF loans. More specifically, lower per capita income, higher inflation, lower GDP growth, lower investments, smaller reserves, higher deficits of the current account, higher growth in government expenditure and higher debt service should all increase the probability that a country ultimately turns to the IMF for funding.

At the same time, however, the willingness of the IMF to provide a loan might be lower in case of high inflation and increasing government expenditure (supply side). Among the "supply side variables" we also include population among the regressors, as larger countries may more easily get financial support to the extent that the "contagion" risk of a balance of payments problem in these countries is higher than in smaller countries (the "too big to fail" hypothesis).

As far as the quality of institutions is concerned, we include a PRCL dummy, i.e. a dummy $=1$ for either free or partly free countries and 0 otherwise (according to the index of "Political Rights and Civil Liberties" or PCRL). The IMF should generally prefer lending to countries that are more liberal and with better institutions (Bird and Rowlands, 2001)..$^{25}$

The countries dummies $C_{i}$ are used to control for country specific characteristics. We also expect them to capture some other supply side (strategic) motivations for IMF loans, which have been examined in the literature: ${ }^{26}$ for example measures of political cohesion or ethnic fractionalisation (leading to conflicts in society and thus undermining the reform efforts), special interests (such as special interests represented in parliament), share of IMF quotas. Finally, $T_{t}$ is a set of time dummies.

To further investigate on the possibly positive relation between IMF loans and the degree of a country's indebtedness we test whether this relation is significantly different than in the case of more (than the sample average) indebted countries respect to the rest of the sample. We do so by interacting the debt (relative to GDP) owed to the IMF, to bilateral and multilateral creditors, to commercial banks and private bondholders with the dummy $H D_{i}$ (high ratios of both debt to export and debt to GDP) which takes the value of one in the case of a more (than the average) indebted country. More specifically, HD is equal to one if a country reaches either a value of its debt to export ratio greater than the sample average (199\%) or a value of its debt to GDP ratio greater than the sample average (56\%). In particular, under the hypothesis of "lending driven by reputation", the amount of loans that the IMF is willing to provide, should increase with the stock of debt held.

\footnotetext{
${ }^{25}$ We did not consider the effect that elections might have on the incentive of a government to turn to the Fund. Przeworski and Vreeland (2000), for example, find evidence which suggests that governments are more likely to enter an agreement early in the election term, hoping that any perceived stigma of signing it will be forgotten before the next elections. Dreher and Vaubel (2004) report that the net credit supplied by the Fund is higher on election time, which in turn suggests that IMF credit might help governments to finance electoral campaigns.

${ }^{26}$ See Barro and Lee (2003) and Ivanova et al. (2000).
} 
Tables 2 and 3 contain all the details on our variable definitions and sources.

\subsection{The estimation method}

We adopt a GLS fixed effect estimator in order to control for countries unobservables and to correct for heteroskedasticity across countries. To account for the short run dynamics of net loans and grants we include a lag of the dependent variable among the regressors. The dynamic specification allows for a correct estimation of the effect of high levels of debt by controlling for the autocorrelation of the IMF disbursements. Indeed, a strong dependence of the IMF disbursements from the IMF debt share in the static specification might actually reflect the autocorrelation of the disbursements which are typically disbursed in a number of installments over time. Without correcting for the short run dynamics, a correlation between loans and debt could reflect a common deterministic trend. The time dummies capture the contemporaneous correlations across countries.

In a typical panel, which has vastly more individuals than time periods, the inclusion of the lagged dependent variable would introduce a bias since the dependent variable, and thus the lagged dependent variable (a right hand regressor), are functions of the individual specific component of the error term. Nickell (1981) shows that in the $\mathrm{AR}(1)$ case the bias in estimating a dynamic fixed effects model becomes less important as T grows. Judson and Owen (1999) test the performance of the least squares fixed effects estimator by means of Monte Carlo simulations, concentrating on panels with typical macroeconomic dimensions (like ours), i.e. small $\mathrm{N}$ and $\mathrm{T}$. Their analysis suggest that the fixed effects estimator performs fairly well when $\mathrm{T}>20$, i.e. with a $\mathrm{T}$ dimension similar to ours.

The fixed effects assumes homoskedasticity and if the assumption is not met then the estimates will be inefficient. A groupwise likelihood ratio heteroskedasticity test was performed on the residuals of the baseline model estimated by OLS. The test is chi-squared distributed with $\mathrm{N}-1$ degrees of freedom, where $\mathrm{N}$ is the number of groups in the sample. The result of the test led to a rejection of the null hypothesis of homoskedasticity across groups for both net loans and grants regressions.

Baltagi and Li (1995) suggest an LM test for serial correlation in fixed effects models where the asymptotic distributions of the test statistics is calculated for large T. Under the alternative assumption for the error autocorrelation structure, i.e. an $\mathrm{AR}(1)$, the null hypothesis of no serial correlation in the disturbance is not rejected at conventional levels. Thus, we did not correct for the autocorrorrelations in the residuals and to adopt a feasible fixed effect GLS estimator, incorporating only heteroskedasticity across countries. 


\section{$7 \quad$ Estimation results}

We estimate our panel of 53 countries for the period 1982 to 2001 by GLS with country-specific effects and time effects. The hypotheses of not significance of country dummies and time dummies were indeed rejected at any reasonable significance level, is shown in Table 4. The results of the estimation of equation (1) is also presented in Table 4.

As expected, IMF loans are rather persistent. Interestingly, and consistently with other results in this literature, economic performance does appear to influence IMF lending . Column 1 shows that the a lower GDP growth, lower international reserves, higher current account deficits, and smaller investments all have a positive effect on IMF lending (i.e. a worse economic performance increase the demand for IMF loans) and these effects are significant at the $5 \%$ level (except for the impact of the reserves level which is significant only at the 10\%). By contrast, per capita GDP and the rate of inflation do not significantly affect IMF loans and the growth rate of government consumption negatively affects the probability of an agreement with the IMF (though not at conventional levels of significance). A heavy debt service burden (relative to exports) increases countries' need for external finance to service their debt and thus their demand for loans, where this effect is highly significant (at the 1\%). ${ }^{27}$ Finally, the dummy for greater "Political Rights and Civil Liberties" has the expected positive sign even if it is not significant at the conventional level.

The important evidence concerns the effect of the debt shares (that we divide into IMF, bilateral, multilateral, commercial bank debt and into debt held by private bondholders) on IMF disbursements, depending on the debt holder type. Column 1 shows that the coefficients on the debt ratios are all positive (except for the debt share of the multilaterals which is negative) but that only the coefficients of the IMF quota is highly significant (at the 5\%), while the coefficient of the share of debt held by commercial banks is also significant but only at the $10 \%$ level. Thus, the IMF looks strikingly more generous with high-(IMF) debt countries than with low-(IMF) debt countries. ${ }^{28}$ The estimated regressions show that IMF disbursements are not significantly related to previous-year disbursements from any other group of creditors: only the lagged dependent variable is strongly significant (at 5\%).

This relation between IMF new loans and IMF debt suggests that debt ownership appears to be an important determinant of the Fund lending decisions. Indeed, IMF disbursements significantly increase with the lagged value of the IMF outstanding debt, while the impact of bilateral and multilateral debt and of the debt share held by private bondholders is not significant, at least at conventional levels. This evidence

\footnotetext{
${ }^{27}$ If interpreted as a supply side type of variable, it could also imply that the IMF is more willing to give loans if a country is used to service its debt.

${ }^{28}$ We should note that this relationship cannot be explained by the IMF being the greatest creditor of these countries. On the contrary, Figure 4 shows that the IMF debt share is the lowest.
} 
clearly confirms that the IMF is positively influenced by its own debt share when deciding about whether continuing lending. In turn, this is consistent with the main prediction of the theoretical model, according to which the longer the relationship between the country and the IMF, the stronger the IMF concern for reputation and so the more willing to lend the IMF will be. ${ }^{29}$

To check the robustness of our results, we re-estimated equations (1) using a dichotomic variable as a proxy of high indebtedness and the results are presented in column 2 of Table 4. Previous results are generally confirmed by the new estimates. IMF disbursements are highly persistent and, among the regressors related to a borrower's economic performance, those having significant coefficients are the same as those presented in column 1. Namely, the growth rate of GDP (negative and significant at 5\%), the level of international reserves (negative and significant at 5\%), the deficit of the current account (now only significant at 10\%) and the total debt service (positive and significant at 1\%). More importantly, while a higher stock of IMF debt is not related to IMF disbursements, for "below the average-indebted countries", in the case of "above the average-indebted countries", the coefficient of the IMF debt share, interacted with the HD dummy, is positive and significant at the $5 \%$ level. Since this result does not apply for all the other debt shares interacted with the HD dummy, we believe this represents further evidence in support of our theoretical results.

Finally, Table 5 shows that these results are robust respect to the inclusion of further lags of the IMF own share of debt. In column 1, only the coefficient of the (two years) lagged IMF debt share is highly significant (at the 5\%), while the impact of bilateral, multilateral and private debt is not significant, at least at conventional levels. In column 2, the coefficient of the (two years) lagged IMF debt share, interacted with the HD dummy, is positive and significant at the $5 \%$ level.

\section{Conclusions}

IMF conditionality specifies policies and structural reforms which borrowing countries must meet in order to obtain an IMF loan. In principle, the Fund can enable governments to implement economic reforms as a result of the leverage it exerts as a creditor. In practice the effectiveness of the conditional lending approach has been limited and numerous empirical studies have shown that a large proportion of Fund

\footnotetext{
${ }^{29}$ This evidence could also be consistent with the hypothesis of the IMF just being concerned with avoiding default with a country, for example not to report an economic loss in its balance sheets (defensive lending). However, even the case of defensive lending looks consistent with the existence of a concern for reputation. A concern for financial stability looks, instead, as a weaker explanation for IMF disbursements. In fact, if it was really an issue, new disbursements should be correlated also with other creditors' debt shares and not only with the IMF one (especially since it is the lowest, as Figure 4 shows).
} 
programs have not been successfully completed. In other words, long-term financial assistance has often come with an increasing debt burden but with only modest reforms.

This unsatisfactory record of conditional lending has been explained referring to both demand side and supply side factors. Among the latter (i.e. sources of inefficiency within the IMF), the literature has pointed out how the existence of bureaucratic and political biases and altruism might be responsible for the lack of credibility characterising the IMF threat of interrupting financial assistance when a country is not complying with conditionality.

In this paper we also argue that the lack of credibility of the termination threat may be one possible explanation of conditional lending failure. However, we suggest that such lack of credibility might be attributed to a concern for reputation of the IMF, which acts at the same time as a creditor and a monitor of reforms.

The IMF desire to hide its surveillance failures, in order to preserve its reputation of being a good monitor, may actually distort its lending decisions towards greater laxity (relative to social optimum) in punishing non-compliance with economic reforms. Moreover, such distortionary incentives (towards excessive lending) may be exacerbated by the length of the relationship between a country and the IMF. In fact, the longer this relationship, the more informative (for the quality of the IMF monitoring) the decision to interrupt a programme will be, since this outcome will have been influenced by many past monitoring actions.

We have empirically tested the hypothesis that larger departures from socially optimal lending rule are associated with longer relationships between a country and the IMF, namely that the longer the IMF has been involved with a country, the larger its disbursements will be. The Fund own share of debt is taken here as a proxy of the duration of its relationship with a country. Estimating a dynamic panel of 53 middle-income countries for the period 1982-2001, we have empirically investigated whether a high debt, and its composition by type of creditors, played an important role in explaining the allocation of IMF disbursements, while controlling for countries' characteristics and their economic performance. Our empirical results show that a higher level of IMF debt significantly increases IMF disbursements. Thus, the empirical evidence is consistent with the main prediction of the theory.

An immediate policy implication of our analysis would be that, in order to eliminate distortions in the IMF lending policy, it would be better to separate its responsibility of lending from that of monitoring. For example, the IMF could be responsible for designing appropriate policy conditions, monitoring and reporting, while, based on such reports, financial support could be decided by a separated intergovernmental body. An alternative proposal would envisage giving back to governments the responsibility for designing and implementing economic reforms. The surveillance function should be limited to the periodical evaluation of the attainment of objectives, rather than to the implementation of particular policy measures (Collier et al., 1997). In 
other words, substituting "procedures conditionality" with "target conditionality", the IMF would be less involved in managing reforms at a micro level and, in turn, it would be less responsible for observed disappointing results in the recipient countries.

\section{References}

[1] Acemoglu, D., Robinson, J.A., Johnson, S., 2001. The Colonial Origins of Comparative Development: An Empirical Investigation. American Economic Review 91, 1369-1401.

[2] Allegret, J.P., Dulbecco, P., 2004. The Institutional Failures of Bretton Woods Institutions Conditionality. Mimeo.

[3] Baltagi, B., Li, Q., 1995. Testing AR(1) against MA(1) disturbances in error component model. Journal of Econometrics 68.

[4] Barro, R.J., Lee, J.W., 2003. IMF Programs: who is chosen and what are the effects? Harvard University, mimeo.

[5] Bird, G. , Rowlands, D., 2001. IMF Lending: How Is It Affected by Economic, Political, and Institutional Factors. Journal of Policy Reform 4, 243-270.

[6] Bird, G., Hussain, M., Joyce, J.P., 2004. Many Happy Returns? Recidivism and the IMF. Journal of International Money and Finance 23.

[7] Birdsall, N., Claessens, S., Diwan, I., 2002. Policy Selectivity Foregone: Debt and Donor Behaviour in Africa. Center for Global Development Working Paper No. 17.

[8] Boot, W.A., Thakor A.V., 1993 Self-Interested Bank Regulation. American Economic Review 83, 206-212.

[9] Burnside, C., Dollar, D., 2000. Aid, Policies and Growth. American Economic Review 90, 847-868.

[10] Collier, P., Guillaumont, P., Guillaumont, S., Gunning J.W., 1997. Redesigning conditionality. World Development 25, 1399-1407

[11] Copelovitch, M., 2004. Private debt composition and the political economy of IMF lending. Harvard University, mimeo.

[12] Drazen, A. 2002. Conditionality and Ownership in IMF Lending: A Political Economy Approach. IMF Staff Papers No. 49, 36-67. 
[13] Dreher, A., Vaubel, R., 2004. Does the IMF Cause Moral Hazard and Political Business Cycles? Evidence from Panel Data. Open Economies Review 15, 5-22.

[14] Easterly, W., 2002. How did highly indebted poor countries become highly indebted? Reviewing two decades of debt relief. World Development 30, 1677-1696.

[15] Joyce, J.P., 2004(a), The Adoption, Implementation and Impact of IMF Programs: A Review of the Evidence. Comparative Economic Studies, forthcoming.

[16] Joyce, J.P., 2004(b), Time Present and Time Past: A Duration Analysis of IMF Program Spells, Review of International Economics, forthcoming.

[17] Judson, R.A., Owen, A.L., 1999. Estimating dynamic panel data models: a guide for macroeconomists. Economic Letters 65, 9-15.

[18] Khan, C.M., Santos, J., 2001. Allocating bank regulatory powers: lender of last resort deposit insurance and supervision. BIS Working Paper No. 102.

[19] Knack, S., Keefer, P., 1995. Institutions and Economic Performance: Cross Country Tests Using Alternative Institutional Models. Economics and Politics 7, 207227.

[20] Knight, M., Santaella, J.A., 1997. Economic Determinants of IMF Financial Arrangements. Journal of Development Economics 54, 405-436.

[21] Ivanova, A., Mayer, W., Mourmouras, A., Anayiotos, G., 2003. What Determines the Implementation of IMF-Supported Programs IMF Working Paper 03/08.

[22] Marchesi, S., Missale, A., 2004. What does motivate lending and aid to the HIPCs? Centro Studi d'Agliano Development Working Papers No. 189.

[23] Mussa, M and Savastano, MA. 2000. The IMF Approach to Economic Stabilization. In Bernanke, BS and Rotemberg, JJ (eds.). NBER Macroeconomics Annual 1999. MIT Press: Cambridge, MA, pp. 79-122.

[24] Nickell, S.J., 1981. Biases in Dynamic Models with Fixed Effects. Econometrica $49,802-816$.

[25] Nunziata, L., 2000. hetgrot.ado: a Stata command for a Likelihood Ratio test for groupwise heteroskedasticity.

[26] Nunziata, L , 2002. xtbac.ado: a Stata command for the Baltagi autocorrelation test in panel data.

[27] Przeworski, A , Vreeland, JR., 2000. The Effect of IMF Programs on Economic Growth. Journal of Development Economics 62, 385-421. 
[28] Ramcharan, R., 2003.Reputation, debt and policy conditionality. IMF Working Paper No. 192.

[29] Repullo, R., 2000. Who should act as lender of last resort? An incomplete contract model. Journal of Money, Credit \& Banking 3, 580-605.

[30] Sturm, J.E., Berger, H., de Haan, J. 2004. Which variables explain decisions on IMF credit? An extreme bounds analysis. mimeo.

[31] Svensson, J., 2000. When Is Foreign Aid Policy Credible? Aid Dependence and Conditionality. Journal of Development Economics 61, 61-80.

[32] The Economis. Which is the victim? March 4th 2004.

[33] The Economist. The sisters at 60. July 22nd 2004.

[34] Vaubel, R., 1986. A Public choice approach to international organizations. Public Choice 51, 39-57.

[35] Vaubel, R., 1991. Problems at IMF. Swiss Review of World Affairs 40, 20-22. 


\section{Appendix: Omitted proofs}

Proof. of Proposition 7

Let's start from the second stage. Let's suppose that $-1 \leq \widetilde{k} \leq \overleftarrow{k}$ and that at $\mathrm{t}=1$ lending (L) has been observed. Applying Bayes' rule, we obtain:

$$
\gamma_{2}(L,-1 \leq \widetilde{k} \leq \overleftarrow{k})=\frac{\gamma \rho_{g}}{\gamma \rho_{g}+(1-\gamma) \rho_{b}}
$$

Then, the IMF private gain from reputation would be equal to: $\gamma_{1}(L)+\delta \gamma_{2}(L,-1 \leq$ $\widetilde{k} \leq \overleftarrow{k}$, where:

$$
\gamma_{1}(L)=\operatorname{prob}(g \mid L)=\frac{\gamma \operatorname{prob}(L \mid g)}{\gamma \operatorname{prob}(L \mid g)+(1-\gamma) \operatorname{prob}(L \mid b)}
$$

and

$$
\operatorname{prob}(L \mid g)=\rho_{g}+\left(1-\rho_{g}\right) \int_{\overleftarrow{k}}^{I+\bar{y}-1} \theta(\widetilde{k}) h\left(\widetilde{k} \mid R_{1}=\widehat{R}_{1}^{R}\right) d
$$

and

$$
\operatorname{prob}(L \mid b)=\rho_{b}+\left(1-\rho_{b}\right) \int_{\overleftarrow{k}}^{I+\bar{y}-1} \theta(\widetilde{k}) h\left(\widetilde{k} \mid R_{1}=\widehat{R}_{1}^{R}\right) d \widetilde{k}
$$

Alternatively, if $-1 \leq \widetilde{k} \leq \overleftarrow{k}$ and at $\mathrm{t}=1$ not lending (NL) has been observed, the IMF private gain from reputation would be equal to: $\gamma_{1}(N L)+\delta \gamma_{1}(N L)$, where:

$$
\gamma_{1}(N L)=\operatorname{prob}(g \mid N L)=\frac{\gamma\left(1-\rho_{g}\right)}{\gamma\left(1-\rho_{g}\right)+(1-\gamma)\left(1-\rho_{b}\right)} .
$$

Therefore, if the IMF chooses to continue lending, irrespective of $\widetilde{k}$ being too small, its private gain in reputation with respect to the alternative strategy would be

$$
G \max =\gamma_{1}(L)+\delta \gamma_{2}(L,-1 \leq \widetilde{k} \leq \overleftarrow{k})-\left(\gamma_{1}(N L)+\delta \gamma_{1}(N L)\right)
$$

which can be easily shown to be positive.

Now let:

$$
W L(\widetilde{k})=1-p_{2}\left(\widehat{R}_{2}(\widetilde{k})\right) I_{2}
$$

be the welfare loss of the second period project. Notice that WL is continuously decreasing with $\widetilde{k}$ (see Proposition 1) and that $\mathrm{WL}()=$.0 when $\widetilde{k}=\bar{k}$. We also assume that the maximum value of $\lambda_{2} W L(\widetilde{k})\left(\lambda_{2} W L(\widetilde{k}=-1)\right.$ is greater than $\lambda_{1} G$.

In order to have equilibrium strategies consistent with the equilibrium beliefs, the following inequality must hold:

$$
\lambda_{2} W L(\widetilde{k}) \geqslant \lambda_{1} G \max , \quad \text { for }-1 \leq \widetilde{k} \leq \overleftarrow{k}
$$


Then, let $\overleftarrow{k}$ be such that

$$
\lambda_{2} W L(\overleftarrow{k})=\lambda_{1} G \max
$$

Therefore, when $-1 \leq \widetilde{k} \leq \overleftarrow{k}$, the IMF has no incentive to deviate from the equilibrium strategy (NL).

Let's now suppose that $\overleftarrow{k}<\widetilde{k} \leq \bar{k}$ and that at $\mathrm{t}=1$ lending (L) has been observed. Noting that, when $\widetilde{k}<\bar{k}$, the first period project has surely failed $\left(\widetilde{k}=\widetilde{k}^{f}\right)$, applying Bayes' rule, we obtain:

$$
\begin{aligned}
& \gamma_{2}(L, \overleftarrow{k}<\widetilde{k} \leq \bar{k})= \\
& \frac{\gamma\left(\rho_{g}\left(1-p_{1}\left(R^{*}\right)\right)+\left(1-\rho_{g}\right) \theta(\widetilde{k})\left(1-p_{1}\left(\widehat{R}_{1}^{R}\right)\right)\right.}{\gamma\left(\rho_{g}\left(1-p_{1}\left(R^{*}\right)\right)+\left(1-\rho_{g}\right) \theta(\widetilde{k})\left(1-p_{1}\left(\widehat{R}_{1}^{R}\right)\right)+(1-\gamma)\left(\rho_{b}\left(1-p_{1}\left(R^{*}\right)\right)+\left(1-\rho_{b}\right) \theta(\widetilde{k})\left(1-p_{1}\left(\widehat{R}_{1}^{R}\right)\right)\right.\right.}
\end{aligned}
$$

from which it is easy to show that (17) reaches its maximum value when $\theta(\overleftarrow{k})=0$ and its minimum when $\theta(\vec{k})=1$ and:

$$
\frac{\partial \gamma_{2}(L, \overleftarrow{k}<\widetilde{k} \leq \bar{k})}{\partial \widetilde{k}}<0
$$

Moreover,

$$
\lim _{\widetilde{k} \rightarrow \overleftarrow{k}} \gamma_{2}(L, \widetilde{k})=\frac{\gamma \rho_{g}}{\gamma \rho_{g}+(1-\gamma) \rho_{b}}
$$

and

$$
\begin{aligned}
& \gamma_{2}(L, \overleftarrow{k}<\widetilde{k} \leq \bar{k})= \\
& \frac{\gamma\left(\rho_{g}\left(1-p_{1}\left(R^{*}\right)\right)+\left(1-\rho_{g}\right)\left(1-p_{1}\left(\widehat{R}_{1}^{R}\right)\right)\right.}{\gamma\left(\rho_{g}\left(1-p_{1}\left(R^{*}\right)\right)+\left(1-\rho_{g}\right)\left(1-p_{1}\left(\widehat{R}_{1}^{R}\right)\right)+(1-\gamma)\left(\rho_{b}\left(1-p_{1}\left(R^{*}\right)\right)+\left(1-\rho_{b}\right)\left(1-p_{1}\left(\widehat{R}_{1}^{R}\right)\right)\right.\right.}
\end{aligned}
$$

Therefore, if the IMF chooses to continue lending, when $\overleftarrow{k}<\widetilde{k} \leq \bar{k}$, its private gain in reputation with respect to the alternative strategy would be:

$$
G(\theta(\widetilde{k}))=\gamma_{1}(L)+\delta \gamma_{2}(L, \overleftarrow{k}<\widetilde{k} \leq \bar{k})-\left(\gamma_{1}(N L)+\delta \gamma_{1}(N L)\right)
$$

where

$$
\frac{\partial G(\theta(\widetilde{k}))}{\partial \widetilde{k}}<0, \lim _{\widetilde{k} \rightarrow \overleftarrow{k}} G(\theta(\widetilde{k}))=G \max \text { and }\left.G(\theta(\widetilde{k}))\right|_{\vec{k} \leq \widetilde{k} \leq \bar{k}}=G \min
$$

Since the probability to continue lending is increasing with $\widetilde{k}$, the signal becomes less informative as capital grows. Notice that $G \mathrm{~min}$ is found substituting (17) into (A-4) and Gmax was defined in A-1. 
For the equilibrium strategies to be consistent with the equilibrium beliefs, the probability to continue lending is found implicitly, solving for $\theta(\widetilde{k})$ :

$$
\lambda_{1} G(\theta(\widetilde{k}))=\lambda_{2} W L(\widetilde{k})
$$

so that, when $\overleftarrow{k} \leq \widetilde{k} \leq \vec{k}$, the payoff associated to the strategy NL is the same as the payoff associated to the strategy L. Notice that $\vec{k}$ is found by solving (A-5) for $\widetilde{k}$ when the probability of continuing lending is 1 . Since $W L(\widetilde{k}=\bar{k})=0$ and $G \min >0$, it is immediate to verify that $\vec{k}<\bar{k}$.

Finally, as $G(\widetilde{k})=G$ min $>0$, when $\vec{k} \leq \widetilde{k} \leq \bar{k}$, it follows that $\lambda_{1} G \min \geq$ $\lambda_{2} W L(\widetilde{k})$. Thus, in this interval, the IMF will lend with probability one even if $R_{1} \neq$ $R^{*}$. 
Table 1: List of middle income countries in the sample
1) Algeria
28) Malaysia
2) Argentina
29) Mauritius
3) Belize
30) Mexico
4) Bolivia
31) Morocco
5) Botswana
32) Oman
6) Brazil
33) Panama
7) Cape Verde
34) Paraguay
8) Chile
35) Peru
9) China
36) Philippines
10) Colombia
37) Poland
11) Costa Rica
38) Romania
12) Dominica
39) Seychelles
13) Dominican Republic
40) Sri Lanka
14) Ecuador
41) St. Kitts and Nevis
15) Egypt, Arab Rep.
42) St. Lucia
16) El Salvador
43) St. Vincent and the Grenadines
17) Fiji
44) Swaziland
18) Gabon
45) Syrian Arab Republic
19) Grenada
46) Thailand
47) Tonga
20) Guatemala
48) Trinidad and Tobago
21) Guyana
22) Honduras
49) Tunisia
23) Hungary
24) Indonesia
50) Turkey
25) Iran, Islamic Rep.
51) Uruguay
52) Vanuatu
26) Jamaica
53) Venezuela, RB
27) Jordan

Source: World Bank, GDF CD-ROM, 2004 
Table 2: Variables definition

\begin{tabular}{lll}
\hline \hline Variable & Definition & Units \\
\hline Population & Population & Billions units \\
Pc-GDP & Gross Domestic Product & Ratio to Population (thousands units) \\
Inflation & Consumer Price Index & Annual Rate of change \\
Gr-GDP & Real GDP growth & Annual Rate of change \\
Reserves & International reserves & Ratio to Imports \\
Current Account & Current Account & Ratio to GDP \\
Investments & Goss fixed domestic investments & Ratio to GDP \\
Gr-Government Consumption & Gov Consumption growth & Annual Rate of change \\
dPRCL & Political Right\&Civil Liberties & Dummy variable=1 for either partially or \\
& & totally free countries; 0 otherwise \\
Total debt service & Total debt service & Ratio to Exports \\
IMF Disbursments & IMF Disbursments & Ratio to GDP \\
Multilateral Disbursments & Bilateral Grants & Ratio to GDP \\
Bilateral Disbursment & Multilateral Disbursments & Ratio to GDP \\
Bank Disbursments & Bank Disbursments & Ratio to GDP \\
Bonds Disbursments & Bonds Disbursments & Ratio to GDP \\
IMF Debt & IMF Debt & Ratio to GDP \\
IMF Debt & IMF Debt & Ratio to GDP \\
Multilateral Debt & Long term Mul Debt & Ratio to GDP \\
Bilateral Debt & Long term Bilateral Debt & Ratio to GDP \\
Bank Debt & Long term Bank Debt & Ratio to GDP \\
Bonds Debt & Long term Bonds Debt & Ratio to GDP \\
\hline \hline
\end{tabular}


Table 3: Data source

\begin{tabular}{ll}
\hline \hline Variable & Source \\
\hline Population & International Financial Statistics \\
Pc-GDP & World Economic Outlook (WEO) \\
Inflation & World Economic Outlook (WEO) \\
Gr-GDP & World Economic Outlook (WEO) \\
International reserves & Global Development Finance (GDF) \\
Current Account & Global Development Finance (GDF) \\
Investments & World Development Indicators \\
Gr-Government Consumption & World Development Indicators \\
Political Rights and Civil Liberties & Freedom House \\
Total debt service & Global Development Finance (GDF) \\
IMF Disbursments & Global Development Finance (GDF) \\
Multilateral Disbursments & Global Development Finance (GDF) \\
Bilateral Disbursment & Global Development Finance (GDF) \\
Bank Disbursments & Global Development Finance (GDF) \\
Bonds Disbursments & Global Development Finance (GDF) \\
IMF Debt & Global Development Finance (GDF) \\
Multilateral Debt & Global Development Finance (GDF) \\
Bilateral Debt & Global Development Finance (GDF) \\
Bank Debt & Global Development Finance (GDF) \\
Bonds Debt & Global Development Finance (GDF) \\
\hline
\end{tabular}


Table 4 IMF Debt Disbursments

\begin{tabular}{|c|c|c|}
\hline & IMF Dis & IMF Dis with interactions \\
\hline Population & $\begin{array}{l}0.0116 \\
(1.300)\end{array}$ & $\begin{array}{l}0.0122 \\
(1.377)\end{array}$ \\
\hline Pc-GDP (-1) & $\begin{array}{l}0.00005 \\
(0.222)\end{array}$ & $\begin{array}{l}0.00002 \\
(0.102)\end{array}$ \\
\hline Inflation $(-1)$ & $\begin{array}{l}0.00004 \\
(0.896)\end{array}$ & $\begin{array}{l}0.00005 \\
(1.039)\end{array}$ \\
\hline Gr-GDP (-1) & $\begin{array}{l}-0.0081^{* *} \\
(2.199)\end{array}$ & $\begin{array}{l}-0.0088^{* *} \\
(2.361)\end{array}$ \\
\hline Reserves (-1) & $\begin{array}{l}-0.0014^{*} \\
(1.823)\end{array}$ & $\begin{array}{l}-0.0016^{\star *} \\
(2.007)\end{array}$ \\
\hline Current Account (-1) & $\begin{array}{l}-0.0055^{* *} \\
(2.172)\end{array}$ & $\begin{array}{l}-0.0043^{*} \\
(1.681)\end{array}$ \\
\hline Investment $(-1)$ & $\begin{array}{l}-0.0069^{* *} \\
(2.291)\end{array}$ & $\begin{array}{l}-0.0069^{* *} \\
(2.281)\end{array}$ \\
\hline Gr-Gov Consumption (-1) & $\begin{array}{l}-0.0009 \\
(1.090)\end{array}$ & $\begin{array}{l}-0.0008 \\
(0.898)\end{array}$ \\
\hline dPRCL & $\begin{array}{l}0.0010 \\
(1.487)\end{array}$ & $\begin{array}{l}0.0009 \\
(1.451)\end{array}$ \\
\hline Total Debt Service $(-1)$ & $\begin{array}{l}0.0035^{* * *} \\
(2.826)\end{array}$ & $\begin{array}{l}0.0034^{* * *} \\
(2.789)\end{array}$ \\
\hline Debt Share M (-1) & $\begin{array}{l}-0.0061 \\
(1.545)\end{array}$ & $\begin{array}{l}-0.0045 \\
(0.929)\end{array}$ \\
\hline Debt Share IMF $(-1)$ & $\begin{array}{l}0.0364^{* *} \\
(2.568)\end{array}$ & $\begin{array}{l}0.0065 \\
(0.351)\end{array}$ \\
\hline Debt Share B (-1) & $\begin{array}{l}0.0026 \\
(1.103)\end{array}$ & $\begin{array}{l}0.0024 \\
(0.607)\end{array}$ \\
\hline Debt Share Banks $(-1)$ & $\begin{array}{l}0.0049^{*} \\
(1.832)\end{array}$ & $\begin{array}{l}-0.0001 \\
(0.028)\end{array}$ \\
\hline Debt Share Bonds $(-1)$ & $\begin{array}{l}0.0015 \\
(0.292)\end{array}$ & $\begin{array}{l}-0.0065 \\
(0.740)\end{array}$ \\
\hline Disbursments M (-1) & $\begin{array}{l}0.0074 \\
(0.488)\end{array}$ & $\begin{array}{l}0.0109 \\
(0.719)\end{array}$ \\
\hline Disbursments IMF (-1) & $\begin{array}{l}0.0596^{* *} \\
(1.985)\end{array}$ & $\begin{array}{l}0.0761^{* *} \\
(2.462)\end{array}$ \\
\hline Disbursments B (-1) & $\begin{array}{l}0.0061 \\
(0.531)\end{array}$ & $\begin{array}{l}0.0084 \\
(0.727)\end{array}$ \\
\hline Disbursments Banks (-1) & $\begin{array}{l}-0.0008 \\
(0.087)\end{array}$ & $\begin{array}{l}0.0024 \\
(0.255)\end{array}$ \\
\hline Disbursments Bonds (-1) & $\begin{array}{l}-0.0216 \\
(1.070)\end{array}$ & $\begin{array}{l}-0.0208 \\
(0.994)\end{array}$ \\
\hline Debt Share M (-1) dHD & & $\begin{array}{l}-0.0015 \\
(0.397)\end{array}$ \\
\hline Debt Share IMF (-1) dHD & & $\begin{array}{l}0.0490^{* *} \\
(2.464)\end{array}$ \\
\hline Debt Share B (-1) dHD & & $\begin{array}{l}-0.0005 \\
(0.117)\end{array}$ \\
\hline Debt Share Banks $(-1)$ dHD & & $\begin{array}{l}0.0031 \\
(0.792)\end{array}$ \\
\hline Debt Share Bonds $(-1) \mathrm{dHD}$ & & $\begin{array}{l}0.0085 \\
(1.028)\end{array}$ \\
\hline Constant & $\begin{array}{l}0.0044^{* *} \\
(2.311) \\
\end{array}$ & $\begin{array}{l}0.0046^{* *} \\
(2.459) \\
\end{array}$ \\
\hline Observations & 1060 & 1060 \\
\hline Number of countries & 53 & 53 \\
\hline Number of years & 20 & 20 \\
\hline SE of regression & 0.011 & 0.011 \\
\hline SE of Dependent variable & 0.013 & 0.013 \\
\hline TD joint significance test & Prob $>$ chi2 $=0.018$ & Prob $>$ chi $2=0.034$ \\
\hline CD joint significance test & Prob $>$ chi2 $=0.067$ & Prob $>$ chi $2=0.193$ \\
\hline
\end{tabular}

Absolute value of $z$ statistics in parentheses * significant at $10 \% ;{ }^{* *}$ significant at $5 \% ;{ }^{* * *}$ significant at $1 \%$ 
Table 5 IMF Debt Disbursments (-2)

\begin{tabular}{|c|c|c|}
\hline & IMF Dis & IMF Dis with interactions \\
\hline Population & $\begin{array}{l}0.0120 \\
(1.180)\end{array}$ & $\begin{array}{l}0.0129 \\
(1.286)\end{array}$ \\
\hline Pc-GDP (-1) & $\begin{array}{l}0.0000 \\
(0.150)\end{array}$ & $\begin{array}{l}-0.0000 \\
(0.118)\end{array}$ \\
\hline Inflation (-1) & $\begin{array}{l}0.0000 \\
(1.004)\end{array}$ & $\begin{array}{l}0.0001 \\
(1.111)\end{array}$ \\
\hline Gr-GDP (-1) & $\begin{array}{l}-0.0080^{* *} \\
(2.145)\end{array}$ & $\begin{array}{l}-0.0088^{* *} \\
(2.322)\end{array}$ \\
\hline Reserves (-1) & $\begin{array}{l}-0.0018^{* *} \\
(2.099)\end{array}$ & $\begin{array}{l}-0.0018^{\star *} \\
(2.139)\end{array}$ \\
\hline Current Account (-1) & $\begin{array}{l}-0.0061^{* *} \\
(2.239)\end{array}$ & $\begin{array}{l}-0.0039 \\
(1.409)\end{array}$ \\
\hline Investment (-1) & $\begin{array}{l}-0.0067^{* *} \\
(2.108)\end{array}$ & $\begin{array}{l}-0.0069^{\star *} \\
(2.144)\end{array}$ \\
\hline Gr-Gov Consumption (-1) & $\begin{array}{l}-0.0012 \\
(1.395)\end{array}$ & $\begin{array}{l}-0.0010 \\
(1.120)\end{array}$ \\
\hline dPRCL & $\begin{array}{l}0.0006 \\
(0.779)\end{array}$ & $\begin{array}{l}0.0007 \\
(0.996)\end{array}$ \\
\hline Total Debt Service $(-1)$ & $\begin{array}{l}0.0038^{* * *} \\
(2.995)\end{array}$ & $\begin{array}{l}0.0039^{* * *} \\
(3.080)\end{array}$ \\
\hline Debt Share M (-1) & $\begin{array}{l}-0.0044 \\
(1.128)\end{array}$ & $\begin{array}{l}-0.0009 \\
(0.176)\end{array}$ \\
\hline Debt Share IMF (-2) & $\begin{array}{l}0.0290 \text { ** } \\
(2.526)\end{array}$ & $\begin{array}{l}-0.0087 \\
(0.526)\end{array}$ \\
\hline Debt Share B (-1) & $\begin{array}{l}0.0028 \\
(1.129)\end{array}$ & $\begin{array}{l}0.0016 \\
(0.383)\end{array}$ \\
\hline Debt Share Banks (-1) & $\begin{array}{l}0.0042 \\
(1.523)\end{array}$ & $\begin{array}{l}-0.0038 \\
(0.864)\end{array}$ \\
\hline Debt Share Bonds (-1) & $\begin{array}{l}0.0019 \\
(0.361)\end{array}$ & $\begin{array}{l}-0.0046 \\
(0.483)\end{array}$ \\
\hline Disbursments M (-1) & $\begin{array}{l}0.0008 \\
(0.054)\end{array}$ & $\begin{array}{l}0.0079 \\
(0.498)\end{array}$ \\
\hline Disbursments IMF (-1) & $\begin{array}{l}0.1564^{\text {** }} \\
(4.239)\end{array}$ & $\begin{array}{l}0.1464^{* * *} \\
(3.970)\end{array}$ \\
\hline Disbursments B (-1) & $\begin{array}{l}-0.0070 \\
(0.580)\end{array}$ & $\begin{array}{l}-0.0044 \\
(0.366)\end{array}$ \\
\hline Disbursments Banks (-1) & $\begin{array}{l}0.0079 \\
(0.795)\end{array}$ & $\begin{array}{l}0.0134 \\
(1.354)\end{array}$ \\
\hline Disbursments Bonds (-1) & $\begin{array}{l}-0.0255 \\
(1.211)\end{array}$ & $\begin{array}{l}-0.0234 \\
(1.085)\end{array}$ \\
\hline Debt Share M (-1) dHD & & $\begin{array}{l}-0.0037 \\
(0.926)\end{array}$ \\
\hline Debt Share IMF (-2) dHD & & $\begin{array}{l}0.0582^{* * *} \\
(3.082)\end{array}$ \\
\hline Debt Share B (-1) dHD & & $\begin{array}{l}0.0007 \\
(0.169)\end{array}$ \\
\hline Debt Share Banks (-1) dHD & & $\begin{array}{l}0.0060 \\
(1.500)\end{array}$ \\
\hline Debt Share Bonds (-1) dHD & & $\begin{array}{l}0.0063 \\
(0.718)\end{array}$ \\
\hline Constant & $\begin{array}{l}0.0023 \\
(0.638) \\
\end{array}$ & $\begin{array}{l}0.0038 \\
(1.034) \\
\end{array}$ \\
\hline Observations & 1007 & 1007 \\
\hline Number of countries & 53 & 53 \\
\hline Number of years & 19 & 19 \\
\hline SE of regression & 0.011 & 0.011 \\
\hline SE of Dependent variable & 0.013 & 0.013 \\
\hline TD joint significance test & Prob $>$ chi $2=0.008$ & Prob>chi2=0.027 \\
\hline CD joint significance test & Prob>chi2 $=0.381$ & Prob>chi2 $=0.363$ \\
\hline
\end{tabular}

Absolute value of $z$ statistics in parentheses ${ }^{*}$ significant at $10 \%$; ${ }^{* *}$ significant at $5 \%$; ${ }^{* *}$ significant at $1 \%$ 
COUNTRY: borrows 1 , chooses $\mathrm{R}_{1}$;

IMF: lends 1;

GT:
Borrows 1- $\widetilde{k}$, chooses $\mathrm{R}_{2}, \widetilde{\mathrm{y}}+\widetilde{\mathrm{I}}_{1}$ is realised.

Observes $\mathrm{R}_{1}$ and $\widetilde{\mathrm{y}}+\widetilde{\mathrm{I}}_{1}$; decides $\mathrm{L}$ or NL;

Observes L or NL;
Observes $\underset{\sim}{\mathrm{R}}$ and $\widetilde{\mathrm{y}}+\widetilde{\mathrm{I}}_{2}$. Observes $\widetilde{k}$.

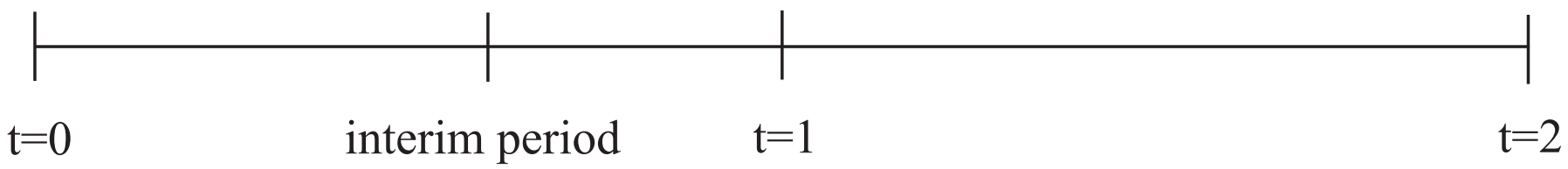

Figure 1

$\lambda_{2} \mathrm{WL}(\widetilde{\mathrm{k}}), \lambda_{1} \mathrm{G}(\theta(\widetilde{\mathrm{k}}))$

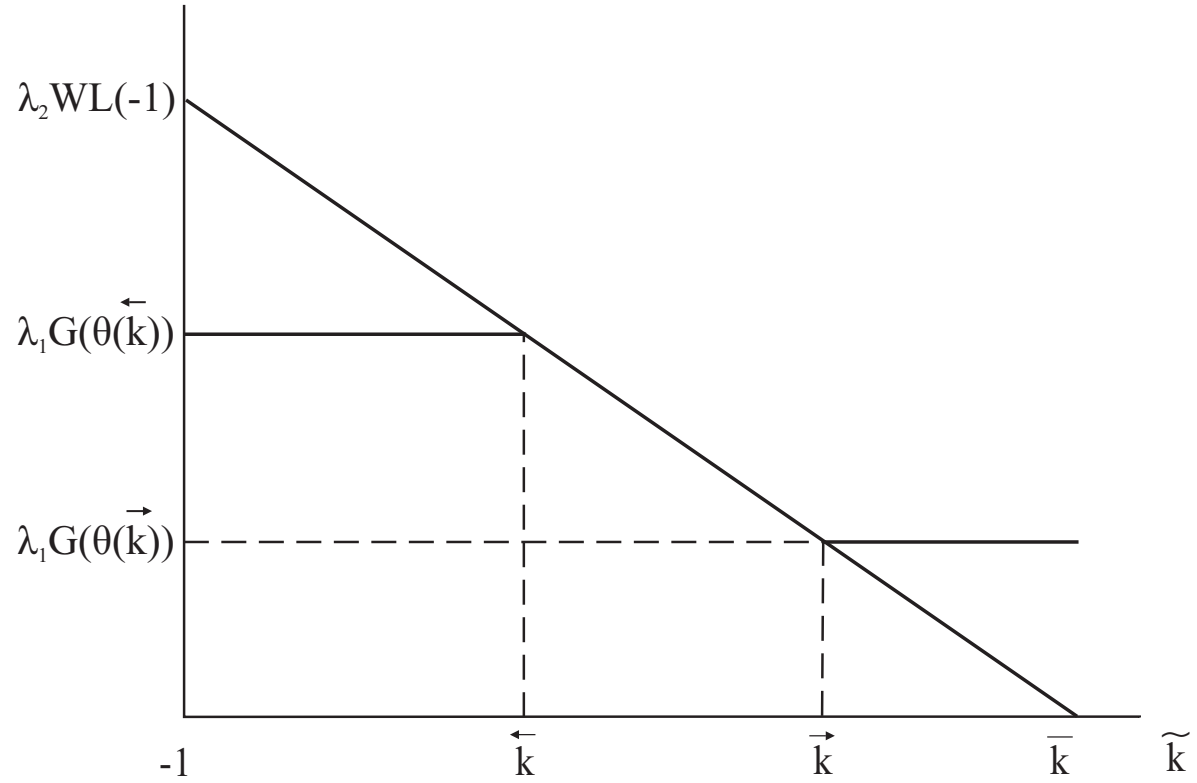

Figure 2 
Figure 3: Long and short term debt shares

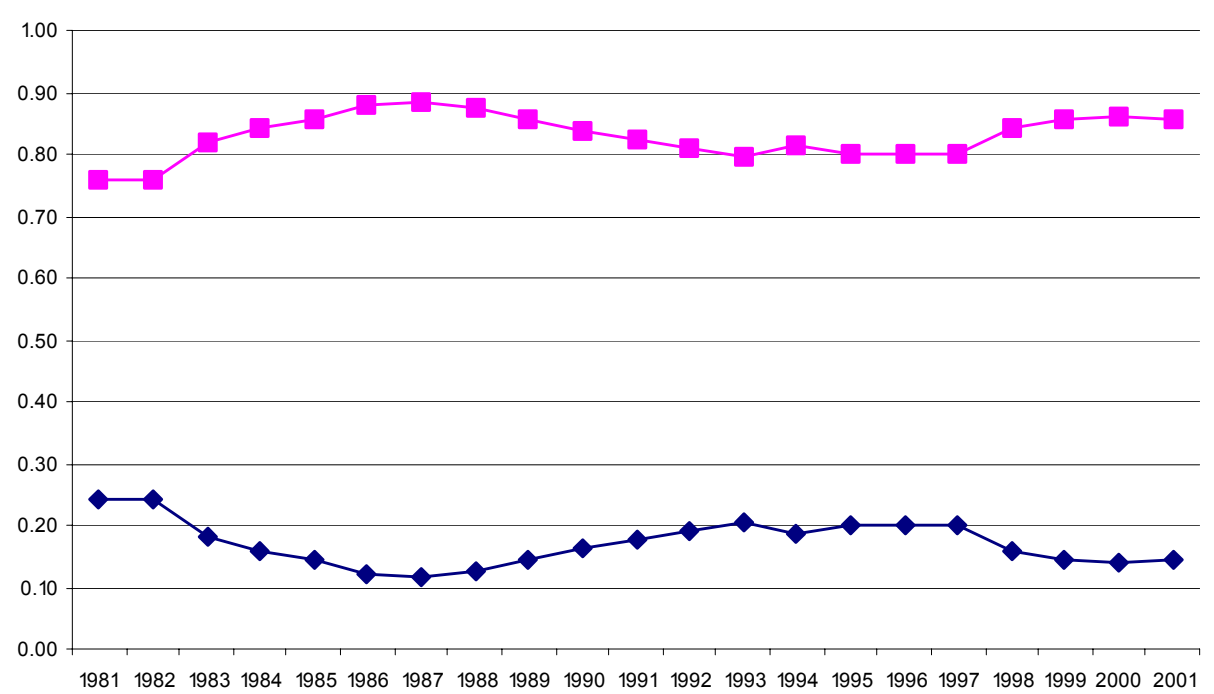

Figure 4: Disaggregated debt shares - middle income countries
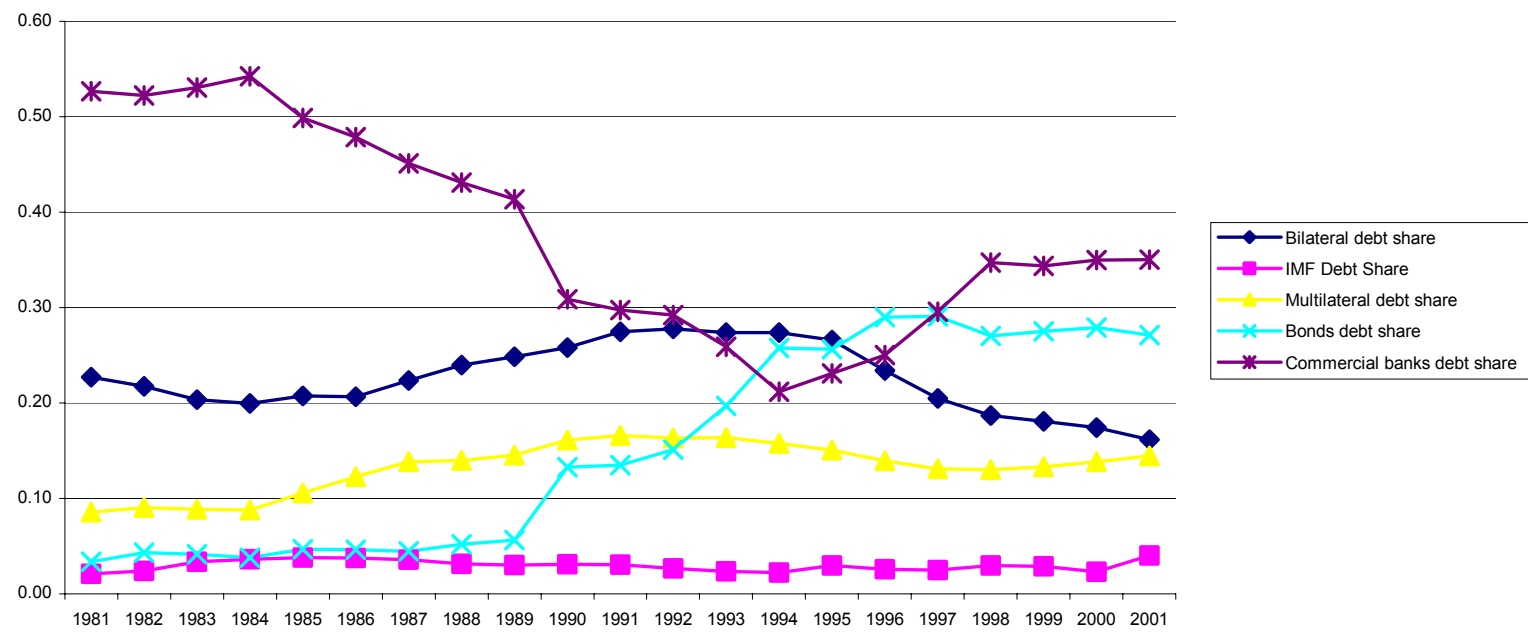